\title{
A systematic review and evaluation of measures for suicidal ideation and behaviors in
}

\section{population-based research}

Philip J. Batterham

The Australian National University

Maria Ftanou, Jane Pirkis

The University of Melbourne

Jacqueline L. Brewer

The Australian National University

Andrew J. Mackinnon

The University of Melbourne

Annette Beautrais

University of Canterbury

A. Kate Fairweather-Schmidt

Flinders University

Helen Christensen

The University of New South Wales

Author Note

Philip J. Batterham and Jacqueline L. Brewer, National Institute for Mental Health Research, The Australian National University, Canberra Australia. Maria Ftanou and Jane Pirkis, Centre for Mental Health, The University of Melbourne, Melbourne Australia. Andrew J. 
Mackinnon, Orygen Youth Health Research Centre, The University of Melbourne, Melbourne Australia. Annette Beautrais, University of Canterbury, Christchurch New

Zealand. A. Kate Fairweather-Schmidt, School of Psychology, Flinders University, Adelaide Australia. Helen Christensen, Black Dog Institute, The University of New South Wales, Sydney Australia.

Correspondence concerning this article should be addressed to Philip Batterham, National Institute for Mental Health Research, 63 Eggleston Road, The Australian National University, Acton 2601 Australia; +61 26125 1031; philip.batterham@anu.edu.au This research is supported by NHMRC APP1042580 Centre of Research Excellence in Suicide Prevention. PB is supported by NHMRC Fellowship 1035262. JP is supported by NHMRC Fellowship 1059261. HC is supported by NHMRC Fellowship 1056964.

Running head: Suicide measures for population research 


\section{Abstract}

The use of measures of suicidal ideation and behavior with sound measurement properties is critical in identifying people most at risk of suicide. In particular, brief self-report measures of suicidal ideation and behaviors are needed for use in large-scale population-based research and in the development and evaluation of suicide prevention programs in the community. This review aimed to identify and recommend psychometrically sound self-report measures of suicidal ideation and behaviors that could be used in population-based research of adults. To identify existing self-report measures for adult use, a systematic search was conducted using MEDLINE and PsycINFO databases. Abstracts, reference lists and previous review papers were screened. Once measures were identified, we used a hierarchical criterion-based approach to assess their utility, psychometric properties and appropriateness for populationbased research. Nineteen measures were evaluated against six criteria. Three brief measures that met all criteria of the evaluation and demonstrated adequate psychometric properties were the Depressive Symptom Index Suicidality Subscale (DSI-SS), Suicidal Behaviors Questionnaire-Revised (SBQ-R) and Suicidal Ideation Attributes Scale (SIDAS). None of the comprehensive measures met all criteria for use in population-based studies, due to financial costs imposed on use, although the Beck Scale for Suicide Ideation (BSSI) and the Adult Suicidal Ideation Questionnaire (ASIQ) had considerable evidence of psychometric robustness. Suicide researchers are encouraged to further establish the validity of scores on these measures across diverse adult populations.

Keywords: $\quad$ suicide, measures, self-report, suicidal ideation, suicide behaviors; population-based research

Word count: $\quad 4,399$ 
Robust measures of suicide risk are necessary for the development and evaluation of suicide prevention and treatment programs and for ongoing clinical and population-based research (Brown, 2001; Range \& Knott, 1997). This paper examines measures that assess the severity of suicidal thoughts and of suicidal behaviors initiated with the intent to die. There are a considerable number of measures developed for this purpose but, to date, there is no globally accepted standard measure recommended for use in population-based studies. Population-based studies may be distinguished from clinical studies in that they tend to focus on a wider range of outcomes and risk factors. Suicidal thoughts and behaviors are less common in the general community than in clinical populations; therefore larger samples are required to identify risk and protective factors for suicide. There is consequently a need for brief measures to reduce response burden, and a parallel requirement for self-report measures to enable collection of data on a large scale where clinician or interviewer assessment of individual participants is cost-prohibitive.

In the past two decades, several reviews of measures assessing suicidal thoughts and behaviors have been published. These reviews have focused on measures that: predict suicide deaths (Rothberg \& Geer-Williams, 1992); have been used in counselling (Westefeld, Range, Rogers et al., 2000), clinical (Perlman, Neufeld, Martin et al., 2011), or forensic settings (Horon, Mcmanus, Schmollinger et al., 2012); have been used with specific populations, such as people with schizophrenia (Preston \& Hansen, 2005) or young people (Goldston, 2000); or have focused on describing the psychometric properties of widely used measures (Range \& Knott, 1997). The most rigorous and robust review of adult measures was conducted by Brown (2001) more than a decade ago. Brown's review identified 11 self-report, and 12 clinician or interviewer administered measures of suicidal ideation and/or suicidal behaviors, along with five attitudinal measures, four reason-for-living measures, three measures 
assessing lethality of attempt and one hopelessness measure. Since this review was conducted, several new measures assessing suicidality have been developed.

There have also been significant theoretical developments since the Brown review, which have recently been summarized by O'Connor and Nock (2014). Such developments may influence the way in which suicidal thoughts and behaviors are conceptualized and measured. For example, the Interpersonal-Psychological Theory of Suicidal Behavior was first described by Joiner (2005). Strong empirical evidence has emerged for the theory, supporting the roles of thwarted belongingness and perceived burdensomeness in the development of suicidal desire and the necessity for acquired capability for suicide (pain tolerance and fearlessness of death) to be present in people who make near-lethal and lethal suicide attempts (Van Orden, Witte, Cukrowicz et al., 2010). Another recent theory, the integrated motivational-volitional model of suicidal behavior (O'Connor, 2011), builds on the stress-diathesis approach adopted in earlier theories (e.g., Mann, Waternaux, Haas et al., 1999) to better specify the motivational phases preceding suicide. These theories of suicidal behavior may lead to more accurate conceptualizations of suicide risk, and consequently, the development of new measures of suicidal thoughts and behaviors.

It is clear that there is a need for greater consistency in the use of measures that assess suicidality so that comparisons may be made across studies (Burless \& De Leo, 2001; Fairweather-Schmidt \& Anstey, 2012). This need for consistency is a priority emphasized in the research agenda for suicide prevention released by the US National Action Alliance for Suicide Prevention (National Action Alliance for Suicide Prevention Research Prioritization Task Force, 2014). However, there are a number of considerations that bear upon the choice of measures for use in the research setting. The psychometric properties of suicide measures are difficult to assess and compare. Validation of scores on suicide measures tends to be conducted with respect to other measures (convergent validity) or simply by assessing 
internal consistency, rather than by comparing to clinical assessment. Dimensionality and factor structure may also be assessed. There has been very little population-based research on the predictive validity of measures currently in use (that is, whether they predict subsequent suicidal behaviors), due to the relatively low prevalence of deaths by suicide in the general population and the difficulty and cost of implementing prospective studies. Nonetheless, some measures are designed to assess current severity rather than predicting future suicidal behaviors. Accordingly, the present review examines both psychometric properties and a number of pragmatic considerations to provide a broad evaluation of the utility of a range of measures in population-based research.

The response burden of a measure is a particularly important consideration, and especially so when that measure is one component of a large population-based survey that extensively assesses a range of risk factors and outcomes. Another consideration is whether measures assess prevalence only (using binary items), or also aim to assess the severity of suicidal thoughts and behaviors (using response scales). Severity measures are more likely to capture the variability necessary to assess changes in suicidal thinking or behavior. Therefore, such measures may be more useful in trials and program evaluations than measures that only assess prevalence of suicidal thoughts and behaviors. Consequently, the current review focuses only on severity measures, for use in population-based research where suicidal ideation or behaviors is an outcome of interest. Nevertheless, other research designs, particularly those with a focus on suicidality as a risk factor rather than an outcome, may benefit more from prevalence measures. A further issue is the need to request permission or pay for the use of certain measures, which may pose barriers to use. A final consideration is that measures should assess both suicidal thoughts and suicidal behaviors, to enable a thorough assessment of suicide-related outcomes. 
This study provides a systematic review of adult, self-report suicide measures for use in population-based research. The focus of the review is on measures that assess the level of severity of suicidal thoughts and behaviors as a dimension. Dimensional measures are capable of capturing a range of risk states and are therefore well suited to assessing suicide risk in population-based samples. Furthermore, prevalence measures that do not assess suicide risk on a dimension tend to have limited demonstration of psychometric performance, one of six criteria used to distinguish the performance of the measures in this review. The other criteria used to evaluate measures are length, appropriate definitions of suicidal thoughts and behaviors, quantitative outcome, level of scientific scrutiny and restrictions on use. The evaluation distinguishes between brief measures, which may be more useful in studies where suicide is a secondary focus, and more comprehensive measures, which might be appropriate for studies focusing primarily on suicide. The aim of the review is to identify adult, self-report suicide measures that have sound psychometric properties and are appropriate for use in population-based research, with a view to promoting more consistent use of identified measures.

\section{Method}

The review adopted a two-stage method: Stage I focused on identifying eligible measures to include in the review and Stage II involved evaluating the quality of the measures against a hierarchical set of criteria.

\section{Stage I: Selection of measures and inclusion criteria}

A literature search using MEDLINE (1946-present) and PsycINFO (1806-present) was conducted in August 2013 using the Ovid interface to identify adult self-report suicide measures to be included in this review. The following search terms were used: ((suicid* or 
'self harm') AND (scale or screen* or validat* or validity or detect* or psychomet*) AND (self-report or self-rat* or questionnaire* or epidemiolog* or survey) AND (symptom* or disorder)). The search excluded duplicates, books and non-English language articles. Abstracts were then screened to identify measures used to assess suicidal thoughts and behaviors in adult populations (aged $\geq 18$ years). Additional measures were sourced from reference list checks, review of the measures identified in Brown's review and recentlycreated measures known to the authors.

Measures retained were those that: contained two or more items that assessed suicidal ideation, plans and/or behaviors; were self-report; and developed for use with the general adult population (i.e., not specific to subgroups such as young adults or older adults). Measures were excluded from this review if they: were clinician-rated; required interviewer or clinician administration; required clinical judgment; were specific to the assessment of suicide in particular populations (e.g., schizophrenia, children, adolescents or older adults); primarily assessed lethality, self-harm behaviors, or focused solely on risk or protective factors for suicide (e.g., hopelessness, reasons for living); or were developed and used only within non-English speaking countries. All measures were considered in accordance with their published mode of administration. Two researchers independently assessed whether the identified measures met eligibility criteria.

\section{Stage II: Evaluation of the quality of measures}

Once eligible measures were identified, a second literature search using MEDLINE and PsycINFO was conducted in March 2014 using the eligible measures' names as the search terms to gather further information about the measures and their psychometric properties. 
Measures were then evaluated based on a hierarchical criterion approach, against the following criteria:

\section{Criteria 1-4-Appropriateness and usability of measures}

1. Explicitly measures suicidal thoughts and behaviors, including at least one item that assesses suicidal ideation, and one item that assesses suicidal behavior (with intent to die)

2. Is brief and easy to administer

3. Yields quantitative data

4. Has been scientifically scrutinized (i.e., published in at least one peer review journal)

\section{Criterion 5 - Psychometric properties}

5. Has sound psychometric properties demonstrated in at least one population-based (nonclinical) study by:

a. internal consistency - determines whether a measure's items measure the same domain;

b. test-retest reliability - assesses the consistency of results at two different time points;

c. construct validity - demonstrates the theoretical structure of scores on the measure, their ability to discriminate and how well they correlates with related variables;

d. concurrent validity - demonstrates the extent to which scores on a measure relate to scores on a similar measure at the same point in time; and/or

e. sensitivity to change - refers to the ability of scores on to detect change over time.

Criterion 6 - Freely available

6. No financial cost or restrictions for use in population research

Measures that did not meet one of the first four criteria in the hierarchy were excluded from review against subsequent criteria, while criteria five and six were used to assess the quality and availability of the measures. 


\section{Results}

\section{Stage I: Identification of measures}

The outcome of the literature review is shown in Figure 1. From 1,117 abstracts, 80 measures used to assess suicidal thoughts and behaviors were identified. However, 61 were not English language self-report measures designed to assess suicidal thoughts and behaviors in the general population (see Figure 1 for details), with the remaining 19 retained for this review. Eleven of these 19 were not identified in Brown's (2001) review. The characteristics of the 19 retained measures are described in Table 1. Six were considered brief self-report measures (five items or less), while the remainder were considered to be more comprehensive self-report measures of suicidal thoughts and behaviors. Stage I excluded measures that were developed for interviewer administration that have not been used widely in self-report format. The 19 measures included in the review were: Adult Suicidal Ideation Questionnaire (ASIQ; Reynolds, 1991), Beck Scale for Suicide Ideation (BSSI; Beck \& Steer, 1991), Concise Health Risk Tracking Scale (CHRT-SR; Trivedi, Wisniewski, Morris et al., 2011), Firestone Assessment of Self-destructive Thoughts (FAST; Firestone \& Firestone, 1998), HarkavyAsnis Suicide Scale (HASS; Harkavy Friedman \& Asnis, 1989), Inventory of Depression and Anxiety Symptoms - Suicide Subscale (IDAS II; Watson, O’Hara, Naragon-Gainey et al., 2012), Positive and Negative Suicide Ideation Inventory (PANSI; Osman, Barrios, Gutierrez et al., 2002), Suicidal Ideation Scale (SIS; Rudd, 1989), Suicide Risk Scale (SRS; Plutchik, Van Praag, Conte et al., 1989), Sheehan Suicide Tracking Scale (S-STS; Coric, Stock, Pultz et al., 2009), Suicide Probability Scale (SPS; Cull \& Gill, 1988), Yale Evaluation of Suicidality (YES; Latham \& Prigerson, 2004), Depressive Symptom Index Suicidality Subscale (DSI-SS; Joiner, Pfaff, \& Acres, 2002), General Health Questionnaire suicide subscale (GHQ-28; Watson, Goldney, Fisher et al., 2001), P4 Screener from the Patient Health Questionnaire (P4; Dube, Kurt, Bair et al., 2010), Psychiatric Symptom Frequency 
Scale suicide subscale (PSF; Lindelow, Hardy, \& Rodgers, 1997), Suicidal Behaviors Questionnaire-Revised (SBQ-R; Osman, Bagge, Gutierrez et al., 2001), Suicidal Ideation Attributes Scale (SIDAS; van Spijker, Batterham, Calear et al., 2014) and Self-Monitoring Suicide Ideation Scale (SMSIS; Clum \& Curtin, 1993).

[Insert Figure 1]

\section{Stage 2: Evaluation of the quality of measures}

To examine the appropriateness of these measures, we compared each against the hierarchical set of criteria outlined in the methods section above. Firstly, appropriateness and usability of the measures were examined against criteria one to four. Once a measure did not meet one of the first four criteria in the hierarchy it was excluded from review against subsequent criteria. Secondly, psychometric properties were considered separately for brief and comprehensive measures in criterion five. Finally, measures were considered in terms of restrictions for use in criterion six.

[Insert Table 1]

\section{Appropriateness and usability of measures}

Criterion 1: Although the GHQ-items, IDAS-II suicide subscale, SMSIS, SRS, PANSI, SPS and the SIS include items that assess suicidal thoughts or behaviors, they do not include items to assess both thoughts and behaviors, or do not assess suicidal intent. Therefore these measures were unable to capture suicidal thoughts and behaviors as defined in this review and were excluded. 
Criterion 2: The FAST is long: more than five times longer than other measures based on items or word count. Although a short form of the FAST exists - the 27-item FASI - the word count is still considerably greater than for other measures included in the review. Due to this additional burden on research participants, the FAST was excluded from further evaluation. Measures were further categorized as comprehensive ( $>5$ items) or brief $(\leq 5$ items, $\leq 200$ words). Flesch-Kincaid Grade Level (Kincaid, Fishburne Jr, Rogers et al., 1975) was also used to assess the literacy level required for each scale. The more comprehensive scales tended to have lower literacy demands than the shorter scales, although most had a reading grade below 7 , indicating a junior high school level of reading proficiency. The one exception was the BSSI, which required the reading level of a high school graduate.

Criterion 3: The P4 screener was the only measure not to generate a quantitative score. The P4 provided an algorithm to help categorize a person's level of risk ranging from low to high. This approach makes it difficult to aggregate scores, compare scores with different participant groups and monitor changes in suicidal thoughts and behaviors. The $\mathrm{P} 4$ was therefore excluded.

Criterion 4: All identified measures had been scientifically scrutinized and published in at least one peer reviewed journal article.

In this first stage of the evaluation, the FAST, GHQ-suicide items, IDAS-II, P4 screener, PANSI, SIS, SMSIS, SPS, and SRS were excluded from further review, leaving 10 (five brief and five comprehensive measures) for consideration of their psychometric properties.

\section{Psychometric properties}

Criterion 5: The second stage of assessment involved evaluating the reported psychometric properties for each of the five comprehensive and five brief measures, with a focus on 
internal consistency, test re-test reliability, construct validity, concurrent validity and sensitivity to change. Table 2 summarizes the psychometric properties of these 10 measures.

[Insert Table 2]

\section{Comprehensive measures}

In assessing the psychometric properties of the five comprehensive measures, we found that:

- The CHRT-SR lacks psychometric testing both in terms of test-retest reliability and sensitivity to change. The CHRT-SR is a relatively new measure and has only been tested in a single clinical sample (240 people with major depressive disorder taking antidepressants). Its psychometric properties need to be replicated in adult population groups.

- The HASS and YES both demonstrated good psychometric properties but sensitivity to change has been demonstrated only for the HASS. The HASS has only been tested in children and adolescent populations and, although it has been used with adults with psychotic illnesses or HIV, its psychometric properties have not been tested in an adult population. Similarly, the YES has only been tested in a small sample of adult bereaved carers who were at high risk of suicide. Therefore, its ability to detect low levels of suicidal thoughts in community samples is yet to be established.

- The ASIQ, BSSI, and S-STS demonstrated excellent performance on at least four of the five psychometric properties. The BSSI and S-STS both demonstrated sensitivity to change. The psychometric properties of the ASIQ and BSSI have been established in a number of different adult populations. However, the S-STS has only been tested in clinical populations, with the exception of a convenience sample of undergraduate 
students. Test-retest reliability was demonstrated for all three scales, with recognition that levels of suicidal thoughts and behaviors may be moderately unstable over extended periods of follow-up.

\section{Brief Measures}

Compared to more comprehensive measures, there was less evidence available that brief measures were psychometrically sound. The PSF suicide subscale has had the least psychometric testing compared to other remaining measures. The DSI-SS, SIDAS lacked assessment of test-retest reliability and sensitivity to change, and the SBQ-R also lacks data on sensitivity to change. The SIDAS is a relatively new measure that has been tested with a web-based sample of 1383 adults. Although the DSI-SS and the SBQ-R have been more widely used, the DSI-SS has only been tested with young adults and the SBQ-R has been psychometrically tested within a relatively small sample. As the absence of psychometric data may not reflect poor performance, all of these measures would benefit from further psychometric testing in the adult population.

After this stage of the evaluation, the ASIQ, BSSI and S-STS were the comprehensive measures with the strongest psychometric properties and were thus retained for evaluation against further criteria. Among the brief measures, the DSI-SS, SBQ-R and SIDAS had evidence of adequate psychometric properties and were retained for evaluation against further criteria.

\section{Restrictions on use}

Criterion 6: The DSI-SS and the SIDAS were the only two measures without restriction for use. The ASIQ and BSSI are copyrighted measures and must be purchased for use, posing 
a financial burden to researchers. In particular, the BSSI requires training and professional qualification for use, and administration must be performed using a required format. The SSTS The SBQ-R requires author permission for use.

In summary, none of the comprehensive measures met criteria for use. For the brief measures, the DSI-SS, SBQ-R and SIDAS met all criteria although, to date, they do not possess the same quantity of psychometric data as the comprehensive measures.

To provide context for the use of the three brief scales, the DSI-SS was developed as a brief screener of suicide risk for use in general health settings. It contains four items that each consist of four graded statements, regarding frequency of suicidal ideation, formulation of plans, controllability of suicidal thoughts and suicidal impulses, with scores ranging from 0-12 (Joiner et al., 2002). The SBQ-R was developed as a brief measure of past severe suicidal thoughts and attempts for use in both clinical and non-clinical settings (Osman et al., 2001). It includes one item assessing a single dimension of severity (thoughts, plans, attempts), one item assessing frequency of suicidal ideation, one item on severity of threat of suicidal behavior, and one item on likelihood of future attempt, with scores ranging from 0 16 (Osman et al., 2001). Finally, the SIDAS was developed for population-based research with a focus on use in internet-based research (van Spijker et al., 2014). It contains four items assessing ideation (frequency, controllability, distress, functional impairment) and one assessing attempt (closeness to attempt), each rated on a 10-point scale, with scores ranging $0-50$.

\section{Discussion}

There is no consensus of a standard, most effective measure for assessing suicidal thoughts and behaviors in population-based studies. The lack of consistency in the measures used makes it difficult to compare results in suicide prevention research, understand the full 
impact of the national and global suicide problem, and plan and evaluate prevention and treatment programs. This review identified and compared 19 self-report adult measures of suicidal thoughts and behaviors. These measures ranged from brief screening measures to comprehensive suicide risk assessment measures. Each of the measures had its own strengths and weaknesses and had undergone various degrees of psychometric testing.

Our provisional recommendations are based on how well measures satisfied the evaluation criteria, the strength of their psychometric properties and how well suited the measures might be to particular research designs (e.g., research designs where suicide is a primary outcome).

\section{Comprehensive self-report measures}

None of the comprehensive measures was recommended by this review for use in population-based research. The BSSI, ASIQ and S-STS met all the criteria except for restrictions on use, specifically financial costs of using these scales for population-based research. In research which is well-resourced, the BSSI or ASIQ may be used to assess severity of suicidal thoughts and behaviors, as these measures have comprehensive psychometric data available. The S-STS is a relatively new measure, with evidence of psychometric properties established in a single study. The ASIQ and BSSI have been used more extensively and exist in translated versions. The BSSI was also the only identified measure that assesses both passive and active suicidal ideation. However, the BSSI was found to have considerably greater literacy demands than all other scales.

\section{Brief self-report measures}

The DSI-SS, SBQ-R and SIDAS are the three brief measures that appear to best meet the evaluation criteria. The strengths of these measures are their ease of administration, 
assessment of suicidal ideation and behavior, cost-free status and their adequate psychometric properties. However, all three measures require further exploration of their psychometric properties, particularly in terms of predictive validity and test-retest reliability. These three brief measures would benefit from further testing in large population-based adult samples. An additional consideration is that the SBQ-R has a higher word count than other brief measures, partly by virtue of lengthy response choices, so this measure may take longer to administer than other brief measures. Nevertheless, the SBQ-R has been used more extensively than the other brief measures.

As noted, the present review focused on measures that assess the level of severity of suicidal thoughts and behaviors as a dimension. There are measures available that assess the prevalence of suicidal ideation and behavior, without assessing a severity dimension. Such measures, which include the PSF and P4, typically use binary responses to identify history of suicidal behavior, and have not been exposed to extensive psychometric testing. Although the present review focused on dimensional measures, studies that only require assessment of previous suicidal thoughts or behaviors as risk factors for subsequent outcomes may find these types of brief measures to be adequate for capturing history of suicidal ideation, intent and behavior. Nevertheless, the DSI-SS, SBQ-R and SIDAS may also be used to assess prevalence and have been shown in this review to possess acceptable psychometric properties.

\section{Implications for researchers}

The findings of this review have a number of implications for suicide researchers. Firstly, in deciding on a suicide measure, researchers need to consider their participant profile, what aspects of suicide risk they want to assess (e.g., thoughts of death, suicidal ideation or suicide attempt), the frequency of measurement and the validity and reliability of 
the measures they are considering. Given that some of the psychometrically sound measures require a payment for use, researchers may need to account for costs of licensing measures in research budgets, rather than opting for measures that have less psychometric data available but are free to use.

Secondly, given that there is an existing range of self-report measures available, it is recommended that researchers consolidate and further explore the psychometric properties of existing measures rather than create new measures, thereby perpetuating the lack of consistency in measurement (Brown, 2001). In particular, to establish which scales most accurately identify individuals at risk for future suicidal behavior, there is a need for additional research into the predictive validity of suicide measures in the population setting. A majority of the studies assessing the psychometric properties of suicide measures have been conducted in clinical rather than population settings, which is a particular challenge for population-based research. Given that a minority of people with suicidal ideation seek help (see, e.g., De Leo, Cerin, Spathonis et al., 2005), the relative scarcity of population validation studies is a gap of concern. Another specific need is for calibration of measures, that is, identifying where along the continuum of suicide risk each measure works and how accurately they do this. Some measures may capture only low-level suicide risk with precision and leave severe levels poorly measured, or vice versa. Such calibration is likely to require new datasets that include multiple measures and use of item response theory to compare severity ratings, analogous to research previously conducted on depression measures (Wahl, Lowe, Bjorner et al., 2014). Such calibration also needs to account for the varying time frames used by different scales.

Lastly, researchers may consider complementing suicide self-report measures with additional self-report measures, assessing factors such as psychiatric illness, social and family 
circumstances, feelings of hopelessness and life stressors, in order to help develop a broader understanding of suicidal thoughts and behaviors.

\section{Limitations}

A feature of the review was that measures were only considered in accordance with their recommended mode of administration. This may have led to the exclusion of measures that were initially designed to be delivered by an interviewer, but have been adopted for use as self-report measures. Relatedly, not all of the measures were designed for use in population settings, disadvantaging measures designed for other settings such as in clinical assessment. Secondly, the review was limited to English language measures, potentially excluding psychometrically sound measures available in other languages. Furthermore, there is limited data available on the relevance of the scales in culturally diverse populations, with most of the scales used exclusively in Western nations. Lastly, measures that primarily assessed lethality, self-harm behaviors or buffers against suicide were beyond the scope of this review.

\section{Conclusions}

This review identified measures that show promise for use as standardized self-report suicide measures for use by adults in population research. Although none of the comprehensive measures met the criteria for recommendation, the ASIQ and BSSI showed the most potential for use in population research, although both measures incur financial costs. Of the brief screening measures, the DSI-SS, SBQ-R and SIDAS have greatest potential for use in population-based research. Further research assessing the performance of these measures is needed to strengthen the present recommendations, with a particular 
emphasis on evaluating predictive validity and calibrating the range of severity assessed by the identified measures. 


\section{References}

Asarnow, J. R., Baraff, L. J., Berk, M., et al. (2011). An emergency department intervention for linking pediatric suicidal patients to follow-up mental health treatment. Psychiatric Services, 62, 1303-1309. doi: http://dx.doi.org/10.1176/appi.ps.62.11.1303

Asarnow, J. R., McArthur, D., Hughes, J., et al. (2012). Suicide attempt risk in youths: utility of the Harkavy-Asnis suicide scale for monitoring risk levels. Suicide and LifeThreatening Behavior, 42, 684-698. doi: http://dx.doi.org/10.1111/j.1943$\underline{278 X .2012 .00122 . X}$

Beck, A., \& Steer, R. (1991). Manual for the Beck Scale for Suicide Ideation. San Antonio, TX: Psychological Corporation.

Beck, A., Steer, R., \& Rantieri, W. (1988). Scale for suicide ideation: Psychometric properties of a self-report version. Journal of Clinical Psychology, 44, 499-505.

Brown, G. (2001). A review of suicide assessment scales for intervention research with adults and older adults. Available at: http://www.suicidology.org/c/document_library/get_file?folderId=235\&name $=D L F E$ -113.pdf.

Burless, C., \& De Leo, D. (2001). Methodological issues in community surveys of suicide ideators and attempters. Crisis, 22, 109-124.

Clum, G. A., \& Curtin, L. (1993). Validity and reactivity of a system of self-monitoring suicide ideation. Journal of Psychopathology and Behavioral Assessment, 15, 375385. doi: http://dx.doi.org/10.1007/BF00965039

Coric, V., Stock, E. G., Pultz, J., et al. (2009). Sheehan Suicidality Tracking Scale (SheehanSTS): Preliminary results from a multicenter clinical trial in generalized anxiety disorder. Psychiatry, 6, 26-31. 
Cotton, C. R., Peters, D. K., \& Range, L. M. (1995). Psychometric properties of the Suicidal Behaviors Questionnaire. Death Studies, 19, 391-397.

Cull, J., \& Gill, W. (1988). Suicide Probability Scale Manua. Los Angeles: Western Psychological Services.

De Leo, D., Cerin, E., Spathonis, K., et al. (2005). Lifetime risk of suicide ideation and attempts in an Australian community: prevalence, suicidal process, and help-seeking behaviour. Journal of Affective Disorders, 86, 215-224. doi: 10.1016/j.jad.2005.02.001

Dube, P., Kurt, K., Bair, M., et al. (2010). The P4 Screener: evaluation of a brief measure for assessing potential suicide risk in 2 randomized effectiveness trials of primary care and oncology patients. The Primary Care Companion to the Journal of Clinical Psychiatry, 12, PCC.10m00978. doi: 10.4088/PCC.10m00978blu

Fairweather-Schmidt, A. K., \& Anstey, K. J. (2012). Prevalence of suicidal behaviours in two Australian general population surveys: methodological considerations when comparing across studies. Social Psychiatry and Psychiatric Epidemiolology, 47, 515522. doi: 10.1007/s00127-011-0369-5

Firestone, R., \& Firestone, L. (1998). Voices in suicide: The relationship between selfdestructive thought processes, maladaptive behavior, and self-destructive manifestations. Death Studies, 22, 411-433.

Fu, K.-w., Liu, K., \& Yip, P. S. (2007). Predictive Validity of the Chinese Version of the Adult Suicidal Ideation Questionnaire: Psychometric Properties and Its Short Version. Psychological Assessment, 19, 422-429.

Goldston, D. (2000). Assessment of suicidal behaviors and risk among children and adolescents. Technical report submitted to NIMH under Contract No. 263-MD909995. 
Harkavy-Friedman, J. M., Nelson, E. A., Venarde, D. F., et al. (2004). Suicidal Behavior in Schizophrenia and Schizoaffective Disorder: Examining the Role of Depression. Suicide and Life-Threatening Behavior, 34, 66-76. doi: http://dx.doi.org/10.1521/suli.34.1.66.27770

Harkavy Friedman, J., \& Asnis, G. (1989). Assessment of suicidal behavior: A new instrument. Psychiatric Annals, 19, 382-387.

Horon, R., Mcmanus, T., Schmollinger, J., et al. (2012). A study of the use and interpretation of standardized suicide risk assessment: Measures within a psychiatrically hospitalized correctional population. Suicide and Life-Threatening Behavior 43, 17 37.

Joiner, T. E. (2005). Why people die by suicide. Cambridge, MA: Harvard University Press. Joiner, T. E., Pfaff, J., \& Acres, J. (2002). A brief screening tool for the suicidal symptoms in adolescents and young adults in general health settings: Reliability and validity data from the Australian National General Practice Youth Suicide Prevention Project. Behaviour Research and Therapy, 40, 471-481.

Khan, A., Khan, S. R. F., Hobus, J., et al. (2011). Differential pattern of response in mood symptoms and suicide risk measures in severely ill depressed patients assigned to citalopram with placebo or citalopram combined with lithium: Role of lithium levels. Journal of Psychiatric Research, 45, 1489-1496. doi: http://dx.doi.org/10.1016/j.jpsychires.2011.06.016

Kincaid, J. P., Fishburne Jr, R. P., Rogers, R. L., et al. (1975). Derivation of new readability formulas (automated readability index, fog count and flesch reading ease formula) for navy enlisted personnel (No. RBR-8-75). Naval Technical Training Command Millington TN Research Branch. 
Latham, A. E., \& Prigerson, H. G. (2004). Suicidality and Bereavement: Complicated Grief as Psychiatric Disorder Presenting Greatest Risk for Suicidality. Suicide and LifeThreatening Behavior, 34, 350-362. doi:

http://dx.doi.org/10.1521/suli.34.4.350.53737

Lindelow, M., Hardy, R., \& Rodgers, B. (1997). Development of a scale to measure symptoms of anxiety and depression in the general UK population: the psychiatric symptom frequency scale. Journal of Epidemiology \& Community Health, 51, 549557.

Mann, J. J., Waternaux, C., Haas, G. L., et al. (1999). Toward a clinical model of suicidal behavior in psychiatric patients. American Journal of Psychiatry, 156, 181-189.

National Action Alliance for Suicide Prevention Research Prioritization Task Force. (2014). A prioritized research agenda for suicide prevention: An action plan to save lives. Rockville, MD.

O'Connor, R. C. (2011). The integrated motivational-volitional model of suicidal behavior. Crisis, 32, 295-298. doi: 10.1027/0227-5910/a000120

O'Connor, R. C., \& Nock, M. K. (2014). The psychology of suicidal behaviour. Lancet Psychiatry, 1, 73-85.

Osman, A., Bagge, C. L., Gutierrez, P. M., et al. (2001). The Suicidal Behaviors Questionnaire-Revised (SBQ-R): validation with clinical and nonclinical samples. Assessment, 8, 443-454.

Osman, A., Barrios, F. X., Gutierrez, P. M., et al. (2002). The Positive and Negative Suicide Ideation (PANSI) inventory: psychometric evaluation with adolescent psychiatric inpatient samples. Journal of Personality Assessment, 79, 512-530. doi:

10.1207/S15327752JPA7903_07 
Osman, A., Kopper, B., Barrios, F. X., et al. (1999). Validation of the Adult Suicidal Ideation Questionnaire and the Reasons for Living Inventory in an adult psychiatric inpatient sample. Psychological Assessment, 11, 115-123.

Perlman, C., Neufeld, E., Martin, L., et al. (2011). Suicide Risk Assessment Inventory: A Resource Guide for Canadian Health care Organizations. Toronto: Ontario Hospital Association and Canadian Patient Safety Institute.

Pinninti, N., Steer, R., Rissmiller, D., et al. (2002). Use of the Beck Scale for Suicide Ideation with psychiatric inpatients diagnosed with schizophrenia, schizoaffective, or bipolar disorders. Behaviour Research and Therapy, 40, 1071-1079.

Plutchik, R., Van Praag, H. M., Conte, H. R., et al. (1989). Correlates of suicide and violence risk: I. The suicide risk measure. Comprehensive Psychiatry, 30, 296-302. doi: http://dx.doi.org/10.1016/0010-440X\%2889\%2990053-9

Preston, E., \& Hansen, L. (2005). A systematic review of suicide rating scales in schizophrenia. Crisis, 26, 170-180.

Preti, A., Sheehan, D. V., Coric, V., et al. (2013). Sheehan Suicidality Tracking Scale (SSTS): Reliability, convergent and discriminative validity in young Italian adults. Comprehensive Psychiatry, 54, 842-849. doi: http://dx.doi.org/10.1016/i.comppsych.2013.03.012

Range, L. M., \& Knott, E. C. (1997). Twenty suicide assessment instruments: evaluation and recommendations. Death Studies, 21, 25-58.

Reynolds, W. (1991). Psychometric characteristics of the Adult Suicidal Ideation Questionnaire in college students. Journal of Personality Assessment, 56, 289-307.

Rothberg, J., \& Geer-Williams, C. (1992). A comparison and review of suicide prediction scales. In R. Maris, A. Berman, J. Maltsberger \& R. Yufit (Eds.), Assessment and prediction of suicide (pp. 15). New York: Guilford Press. 
Rudd, M. (1989). The prevalence of suicidal ideation among college students. Suicide and Life-Threatening Behavior 19, 173-183.

Steer, R., Rissmiller, D., Ranieri, W., et al. (1993). Dimensions of suicidal ideation in psychiatric inpatients. Behaviour Research And Therapy, 31, 229-236.

Trivedi, M. H., Wisniewski, S. R., Morris, D. W., et al. (2011). Concise Health Risk Tracking scale: a brief self-report and clinician rating of suicidal risk. Journal of Clinical Psychiatry, 72, 757-764. doi: http://dx.doi.org/10.4088/JCP.11m06837

Van Orden, K. A., Witte, T. K., Cukrowicz, K. C., et al. (2010). The interpersonal theory of suicide. Psychological review, 117, 575-600.

van Spijker, B. A. J., Batterham, P. J., Calear, A. L., et al. (2014). The Suicidal Ideation Attributes Scale (SIDAS): Community-based validation study of a new scale for the measurement of suicidal ideation. Suicide and Life-Threatening Behavior, 44, 408419. doi: $10.1111 /$ sltb.12084

van Spijker, B. A. J., van Straten, A., \& Kerkhof, A. J. F. M. (2012). Reducing Suicidal Ideation: Cost-Effectiveness Analysis of a Randomized Controlled Trial of Unguided Web-Based Self-help. Journal of Medical Internet Research, 14, 141.

Wahl, I., Lowe, B., Bjorner, J. B., et al. (2014). Standardization of depression measurement: a common metric was developed for 11 self-report depression measures. Journal of Clinical Epidemiology, 67, 73-86. doi: 10.1016/j.jclinepi.2013.04.019

Watson, D., Goldney, R., Fisher, L., et al. (2001). The measurement of suicidal ideation. Crisis: Journal of Crisis Intervention \& Suicide, 22, 12-14.

Watson, D., O’Hara, M. W., Naragon-Gainey, K., et al. (2012). Development and validation of new anxiety and bipolar symptom scales for an expanded version of the IDAS (the IDAS-II). Assessment, 19, 399-420. doi: http://dx.doi.org/10.1177/1073191112449857 
Westefeld, S., Range, M., Rogers, R., et al. (2000). Suicide: An Overview. The Counseling Psychologist, 28, 445-509. 
Figure 1: Flow diagram of systematic review to identify adult self-report suicide measures

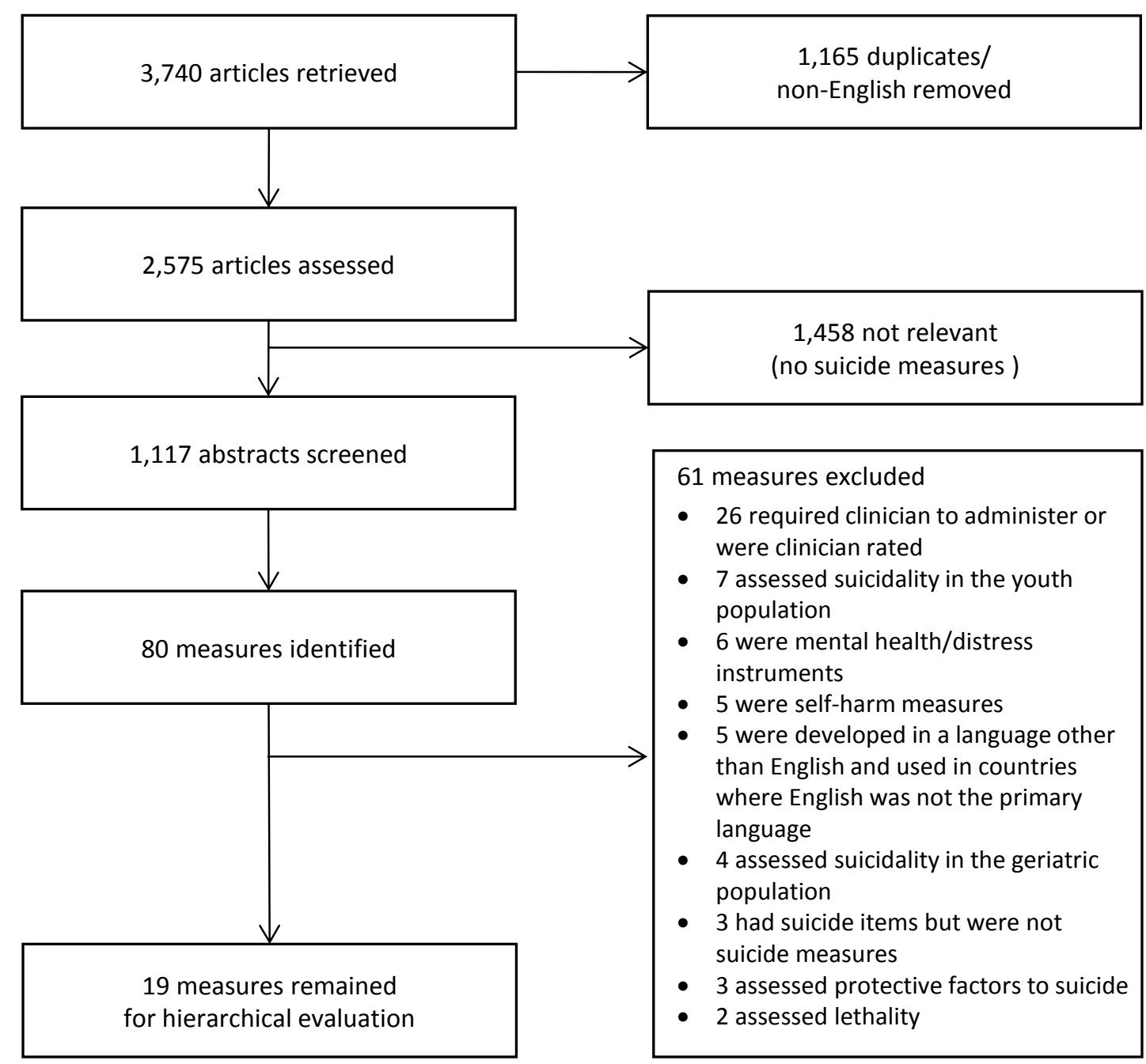


$\underline{\text { Table 1: }}$

Characteristics of suicide self-report measures

\begin{tabular}{|c|c|c|c|c|c|c|c|}
\hline Measure & Year & $\begin{array}{l}\text { Countries } \\
\text { used in }\end{array}$ & Description & Items & $\begin{array}{l}\text { Word } \\
\text { Count/ } \\
\text { Reading } \\
\text { grade }\end{array}$ & Response format & Timeframe \\
\hline \multicolumn{8}{|c|}{ Comprehensive measures } \\
\hline $\begin{array}{l}\text { Adult Suicidal Ideation } \\
\text { Questionnaire (ASIQ) } \\
\text { (Reynolds, 1991) }\end{array}$ & 1991 & $\begin{array}{l}\text { USA } \\
\text { India } \\
\text { Hong Kong } \\
\text { Canada } \\
\text { Pakistan }\end{array}$ & Measures frequency of suicide ideation and behavior. & 25 & $\begin{array}{l}417 \\
2.7\end{array}$ & $\begin{array}{l}\text { 7-point Likert scale ranging } \\
\text { from } 0 \text { "never had the thought" } \\
\text { to } 6 \text { "almost every day" }\end{array}$ & Past month \\
\hline 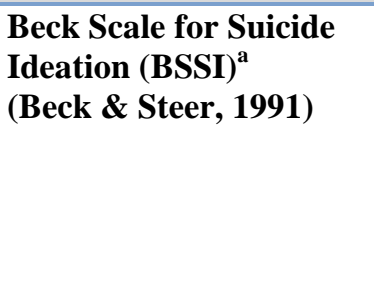 & 1991 & $\begin{array}{l}\text { USA } \\
\text { China } \\
\text { Canada } \\
\text { Norway } \\
\text { Austria } \\
\text { Japan } \\
\text { Portugal }\end{array}$ & $\begin{array}{l}\text { Designed to detect and measure intensity of attitudes, } \\
\text { behaviors, and plans to commit suicide. Identical } \\
\text { item content to the Scale for Suicide Ideation } \\
\text { clinician rated measure. }\end{array}$ & 21 & $\begin{array}{l}354 \\
13.2\end{array}$ & $\begin{array}{l}\text { First } 19 \text { items rated on a 3-point } \\
\text { scale }(0-2) \text { with varying } \\
\text { descriptors for each item, higher } \\
\text { ratings reflect greater severity. } \\
\text { Final two items assess number } \\
\text { of previous attempts and } \\
\text { seriousness of intent. }\end{array}$ & Past 7 days \\
\hline $\begin{array}{l}\text { Firestone Assessment of } \\
\text { Self-destructive } \\
\text { Thoughts (FAST) } \\
\text { (Firestone \& Firestone, } \\
\text { 1998) }\end{array}$ & 1996 & $\begin{array}{l}\text { USA } \\
\text { Canada }\end{array}$ & $\begin{array}{l}\text { Measures the frequency of } 11 \text { levels of self- } \\
\text { destructive thoughts including self-depreciation, self- } \\
\text { denial, cynical attitude, isolation, self-contempt, } \\
\text { addiction, hopelessness, giving up, self-harm, suicide } \\
\text { plans and suicide injunction. }\end{array}$ & 84 & $\begin{array}{c}2,837 \\
\text { N/A }\end{array}$ & $\begin{array}{l}\text { 5-point Likert Scale ranging } \\
\text { from } 0 \text { "never" to } 4 \text { "most of the } \\
\text { time" }\end{array}$ & Unspecified \\
\hline $\begin{array}{l}\text { Harkavy-Asnis Suicide } \\
\text { Scale (HASS) } \\
\text { (Harkavy Friedman \& } \\
\text { Asnis, 1989) }\end{array}$ & 1989 & USA & $\begin{array}{l}\text { The scale has three sections that can be used } \\
\text { independently of each other. } \\
\text { 1. HASS-DEMO: demographic information related to } \\
\text { increased risk of suicidal behavior. } \\
\text { 2. HASS-I: frequency and severity of suicide } \\
\text { behaviors, ideation and substance abuse over two } \\
\text { week period. } \\
\text { 3. HASS-II: same questions as HASS I, but } \\
\text { references lifetime. }\end{array}$ & $\begin{array}{l}\text { HASS- } \\
\text { DEMO } \\
\quad 16 \\
\text { HASS-I / } \\
\text { HASS-II } \\
21\end{array}$ & $\begin{array}{l}321 \\
\\
\\
195 \\
4.7\end{array}$ & $\begin{array}{l}\text { HASS DEMO - Yes / No } \\
\text { HASS-I \& HASS-II - 5-point } \\
\text { Likert scale ranging from } 0 \\
\text { "never" to } 4 \text { "daily" }\end{array}$ & $\begin{array}{l}\text { Past two } \\
\text { weeks } \\
\text { Lifetime }\end{array}$ \\
\hline
\end{tabular}




\begin{tabular}{|c|c|c|c|c|c|c|c|}
\hline Measure & Year & $\begin{array}{l}\text { Countries } \\
\text { used in }\end{array}$ & Description & Items & $\begin{array}{l}\text { Word } \\
\text { Count/ } \\
\text { Reading } \\
\text { grade }\end{array}$ & Response format & Timeframe \\
\hline $\begin{array}{l}\text { Inventory of Depression } \\
\text { and Anxiety Symptoms } \\
\text { (IDAS II)- Suicide } \\
\text { Subscale } \\
\text { (Watson et al., 2012) }\end{array}$ & 2007 & $\begin{array}{l}\text { USA } \\
\text { Serbia } \\
\text { Singapore }\end{array}$ & $\begin{array}{l}\text { Measures frequency of suicidal thoughts and } \\
\text { behaviors. }\end{array}$ & 6 & $\begin{array}{l}107 \\
2.4\end{array}$ & $\begin{array}{l}\text { 5-point Likert scale ranging } \\
\text { from } 1 \text { "not at all" to } 5 \\
\text { "extremely". }\end{array}$ & Past 2 weeks \\
\hline $\begin{array}{l}\text { Positive and Negative } \\
\text { Suicide Ideation } \\
\text { Inventory (PANSI) }^{\text {a }} \\
\text { (Osman et al., 2002) }\end{array}$ & 1998 & $\begin{array}{l}\text { USA } \\
\text { China }\end{array}$ & $\begin{array}{l}\text { Measures positive and negative thoughts associated } \\
\text { with suicide attempts. }\end{array}$ & 14 & $\begin{array}{l}248 \\
3.1\end{array}$ & $\begin{array}{l}\text { 5-point Likert scale ranging } \\
\text { from } 1 \text { "none of the time" to } 5 \\
\text { "most of the time". }\end{array}$ & Past 2 weeks \\
\hline $\begin{array}{l}\text { Suicidal Ideation Scale } \\
\text { (SIS) }^{\mathrm{a}} \\
\text { (Rudd, 1989) }^{\text {Rudd }}\end{array}$ & 1989 & $\begin{array}{l}\text { USA } \\
\text { UK } \\
\text { Australia }\end{array}$ & $\begin{array}{l}\text { Measures presence, severity and intensity of suicidal } \\
\text { thinking and the presence or absence of prior suicide } \\
\text { attempts. }\end{array}$ & 10 & $\begin{array}{l}104 \\
1.9\end{array}$ & $\begin{array}{l}\text { 5-point Likert scale ranging } \\
\text { from } 1 \text { "never or none of the } \\
\text { time" to } 5 \text { "always or a great } \\
\text { many times" }\end{array}$ & $\begin{array}{l}\text { Past } 12 \\
\text { months }\end{array}$ \\
\hline $\begin{array}{l}\text { Suicide Risk Scale (SRS) } \\
\text { (Plutchik et al., 1989) }\end{array}$ & 1989 & $\begin{array}{l}\text { USA } \\
\text { Spain } \\
\text { Israel }\end{array}$ & $\begin{array}{l}\text { Assesses past history of suicide attempts, present } \\
\text { strength of suicidal impulses, symptoms of } \\
\text { depression and feelings of hopelessness and } \\
\text { helplessness. }\end{array}$ & 24 & $\begin{array}{l}249 \\
5.1\end{array}$ & Yes / No & Lifetime \\
\hline $\begin{array}{l}\text { Sheehan Suicide } \\
\text { Tracking Scale (S-STS) } \\
\text { (Coric et al., 2009) }\end{array}$ & 2009 & $\begin{array}{l}\text { USA } \\
\text { Italy }\end{array}$ & $\begin{array}{l}\text { Tracks treatment emergent suicidal ideation and } \\
\text { behaviors. Items assess the severity of suicidal } \\
\text { ideation and behavior. }\end{array}$ & 11 & $\begin{array}{l}179 \\
6.2\end{array}$ & $\begin{array}{l}\text { 5-point Likert scale ranging } \\
\text { from } 0 \text { "not at all" to } 4 \\
\text { "extremely" }\end{array}$ & Past week \\
\hline $\begin{array}{l}\text { Suicide Probability Scale } \\
\text { (SPS) }^{\mathrm{a}} \\
(\text { Cull \& Gill, 1988) }\end{array}$ & 1988 & $\begin{array}{l}\text { USA } \\
\text { China } \\
\text { Canada } \\
\text { Turkey } \\
\text { Italy } \\
\text { Sweden } \\
\text { Austria }\end{array}$ & $\begin{array}{l}\text { Measures current suicidal ideation, hopelessness, } \\
\text { negative evaluation and hostility. }\end{array}$ & 36 & $\begin{array}{l}334 \\
2.3\end{array}$ & $\begin{array}{l}\text { 4-point Likert scale ranging } \\
\text { from } 1 \text { "none or a little bit of the } \\
\text { time" to } 4 \text { "most or all of the } \\
\text { time" }\end{array}$ & Current \\
\hline $\begin{array}{l}\text { Yale Evaluation of } \\
\text { Suicidality (YES) } \\
\text { (Latham \& Prigerson, } \\
\text { 2004) }\end{array}$ & 2004 & USA & $\begin{array}{l}\text { Assesses presence of current suicidal thoughts and } \\
\text { actions, and past and planned attempts. }\end{array}$ & 13 & $\begin{array}{l}251 \\
5.1\end{array}$ & True / False & $\begin{array}{l}\text { Past } 12 \\
\text { months }\end{array}$ \\
\hline \multicolumn{8}{|c|}{ Brief measures } \\
\hline $\begin{array}{l}\text { Depressive Symptom } \\
\text { Index Suicidality } \\
\text { Subscale (DSI-SS) } \\
\text { (Joiner et al., 2002) }\end{array}$ & 1996 & $\begin{array}{l}\text { Australia } \\
\text { USA } \\
\text { Canada }\end{array}$ & $\begin{array}{l}\text { Measures the frequency and intensity of suicidal } \\
\text { ideas and impulses. }\end{array}$ & 4 & $\begin{array}{l}45 \\
5.7\end{array}$ & $\begin{array}{l}\text { 3-point scales }(0-2) \text { with varying } \\
\text { descriptors for each item, higher } \\
\text { ratings reflect greater severity }\end{array}$ & Past 2 weeks \\
\hline
\end{tabular}




\begin{tabular}{|c|c|c|c|c|c|c|c|}
\hline Measure & Year & $\begin{array}{l}\text { Countries } \\
\text { used in }\end{array}$ & Description & Items & $\begin{array}{l}\text { Word } \\
\text { Count/ } \\
\text { Reading } \\
\text { grade }\end{array}$ & Response format & Timeframe \\
\hline $\begin{array}{l}\text { General Health } \\
\text { Questionnaire (GHQ-28) } \\
\text { suicide subscale } \\
\text { (Watson et al., 2001) }\end{array}$ & 2001 & Australia & $\begin{array}{l}\text { Assesses the presence, frequency and severity of } \\
\text { suicidal ideation. }\end{array}$ & 4 & $\begin{array}{l}81 \\
7.1\end{array}$ & $\begin{array}{l}\text { 4-point Likert scale ranging } \\
\text { from } 0 \text { "not at all" to } 3 \text { "rather } \\
\text { more than usual" }\end{array}$ & Past month \\
\hline $\begin{array}{l}\text { P4 Screener } \\
\text { (Dube et al., 2010) }\end{array}$ & 2010 & Canada & $\begin{array}{l}\text { Assesses past suicide attempts, future plans, } \\
\text { probability of completing suicide, and preventive } \\
\text { factors. }\end{array}$ & 4 & $\begin{array}{l}87 \\
6.6\end{array}$ & $\begin{array}{l}\text { Yes / No and brief qualitative } \\
\text { descriptors }\end{array}$ & $\begin{array}{l}\text { Past month } \\
\text { Lifetime }\end{array}$ \\
\hline $\begin{array}{l}\text { Psychiatric Symptom } \\
\text { Frequency Scale PSF } \\
\text { (suicide subscale) } \\
\text { (Lindelow et al., 1997) }\end{array}$ & 1997 & $\begin{array}{l}\text { Australia } \\
\text { UK }\end{array}$ & $\begin{array}{l}\text { Assesses presence of suicidal thoughts, plans and } \\
\text { attempts. }\end{array}$ & 4 & $\begin{array}{l}56 \\
3.4\end{array}$ & Yes / No & $\begin{array}{l}\text { Past } 12 \\
\text { months } \\
\text { Current }\end{array}$ \\
\hline $\begin{array}{l}\text { Suicidal Behaviors } \\
\text { Questionnaire-Revised } \\
\text { (SBQ-R) }^{\mathbf{a}} \\
\text { (Osman et al., 2001) }^{\text {Osman }}\end{array}$ & 2001 & $\begin{array}{l}\text { USA } \\
\text { Asia } \\
\text { Australia }\end{array}$ & $\begin{array}{l}\text { Assesses previous suicidal attempts, frequency of } \\
\text { suicidal ideation, previous suicidal communication } \\
\text { and subjective likelihood of future suicide attempt. } \\
\text { Developed based on Linehan's 7-page SBQ interview } \\
\text { format, which was later adapted to SBQ-14. }\end{array}$ & 4 & $\begin{array}{l}171 \\
6.5\end{array}$ & $\begin{array}{l}\text { Either 5-or 7-point Likert scales, } \\
\text { with varying descriptors. For the } \\
\text { first } 3 \text { items, higher ratings } \\
\text { reflect greater severity, reversed } \\
\text { for item } 4 .\end{array}$ & $\begin{array}{l}\text { Current } \\
\text { Lifetime }\end{array}$ \\
\hline $\begin{array}{l}\text { Suicidal Ideation } \\
\text { Attributes Scale (SIDAS) } \\
\text { (van Spijker et al., 2014) }\end{array}$ & 2013 & Australia & $\begin{array}{l}\text { Measures suicidal ideation in terms of frequency, } \\
\text { controllability, closeness to attempt, distress, and } \\
\text { interference with daily activities. }\end{array}$ & 5 & $\begin{array}{l}91 \\
6.6\end{array}$ & $\begin{array}{l}\text { 10-point rating scale, each with } \\
\text { varying descriptors, where } \\
\text { higher ratings reflect greater } \\
\text { severity (item } 2 \text { reverse scored) }\end{array}$ & Past month \\
\hline $\begin{array}{l}\text { Self-Monitoring Suicide } \\
\text { Ideation Scale } \\
\text { (SMSIS) }^{\mathrm{a}} \\
\text { (Clum \& Curtin, 1993) }\end{array}$ & 1993 & USA & $\begin{array}{l}\text { Assesses the intensity, duration, and level of control } \\
\text { over suicide ideation. The measure was adapted from } \\
\text { Beck's Scale for Suicide Ideation. }\end{array}$ & 3 & $\begin{array}{l}53 \\
7.6\end{array}$ & $\begin{array}{l}\text { Four or five point scales, each } \\
\text { with different descriptors, where } \\
\text { higher ratings reflect greater } \\
\text { severity }\end{array}$ & Daily \\
\hline
\end{tabular}

${ }^{\text {a }}$ Previously identified in Brown's (2000) review of Suicide Assessment Measures for Intervention with Adults and Older Adults; N/A not available 
Table 2:

Psychometric properties of adult self-report measures

\begin{tabular}{|c|c|c|c|c|c|c|}
\hline \multirow[t]{2}{*}{ Measure } & \multirow[t]{2}{*}{ Sample } & \multicolumn{2}{|c|}{ Reliability $^{\text {ab }}$} & \multicolumn{2}{|l|}{ Validity $^{\mathbf{b}}$} & \multirow[b]{2}{*}{ Sensitivity to change } \\
\hline & & $\begin{array}{l}\text { Internal } \\
\text { consistency }\end{array}$ & Test-retest & Concurrent & Construct & \\
\hline \multicolumn{7}{|c|}{ Comprehensive measures } \\
\hline ASIQ & $\begin{array}{l}\text { Populations tested: } \\
1104 \text { Undergraduates } \\
570 \text { Community adults } \\
361 \text { Psychiatric outpatients } \\
205 \text { Psychiatric inpatients } \\
\text { Used with: } \\
\text { Psychiatric inpatients } \\
\text { Undergraduates } \\
\text { Schizophrenia } \\
\text { Forensic population } \\
\text { Police officers }\end{array}$ & $\begin{array}{l}\text { Excellent ( } \alpha \\
\text { range .96-.98) } \\
\text { (Fu, Liu, \& Yip, } \\
\text { 2007; Reynolds, } \\
\text { 1991) }\end{array}$ & $\begin{array}{l}\text { Excellent over } 1 \\
\text { week ( } r \text { range .95- } \\
.86) \\
\text { (Reynolds, 1991) }\end{array}$ & $\begin{array}{l}\text { Correlated with the Hamilton } \\
\text { Depression Scale }(r=.77) \text {, } \\
\text { Beck Depression Inventory ( } r \\
=.60) \text {, Rosenberg Self-Esteem } \\
\text { Scale }(r=.48) \text { the MMPI } \\
\text { depression scale }(r=.64) \\
\text { (Reynolds, 1991) }\end{array}$ & $\begin{array}{l}\text { Three factors: suicidal } \\
\text { ideation, response of others, } \\
\text { and thinking of ways people } \\
\text { kill themselves. All items } \\
\text { primarily loaded with one } \\
\text { factor, loadings ranging from } \\
.50-.88 \text {.(Reynolds, 1991) } \\
\text { Differentiates between } \\
\text { community and psychiatric } \\
\text { patients. Scores predict suicide } \\
\text { attempts at } 3 \text { mo follow-up of } \\
\text { psychiatric inpatients (Osman, } \\
\text { Kopper, Barrios et al., 1999) }\end{array}$ & Not reported \\
\hline BSSI & $\begin{array}{l}\text { Population tested: } \\
330 \text { Adult inpatients } \\
55 \text { Psychiatric outpatients } \\
180 \text { psychiatric inpatients } \\
108 \text { Adolescent inpatient } \\
\text { sample } \\
\text { Validated in Uganda, China, } \\
\text { Pakistan } \\
\text { Used with: } \\
\text { Inpatients } \\
\text { Outpatients } \\
\text { Adolescents } \\
\text { Large community samples } \\
\text { Emergency department } \\
\text { patients }\end{array}$ & $\begin{array}{l}\text { Good to } \\
\text { excellent ( } \alpha \\
\text { range .87-.97) } \\
\text { (Steer, } \\
\text { Rissmiller, } \\
\text { Ranieri et al., } \\
\text { 1993) }\end{array}$ & $\begin{array}{l}\text { Good to excellent } \\
\text { over } 1 \text { week }(r \\
\text { range .54-.88) } \\
\text { (Pinninti, Steer, } \\
\text { Rissmiller et al., } \\
\text { 2002) }\end{array}$ & $\begin{array}{l}\text { Correlated with Scale for } \\
\text { Suicide Ideation ( } r \text { range } .90 \text { - } \\
.94 \text { ) Beck Depression } \\
\text { Inventory ( } r \text { range .64-.75) } \\
\text { Beck Hopelessness Scale ( } r \\
\text { range .53-.62) (Beck, Steer, \& } \\
\text { Rantieri, 1988) and prior } \\
\text { attempts }(r=.46 \text { ) (Pinninti et } \\
\text { al., 2002) } \\
\text { No significant difference } \\
\text { between clinician-rated Scale } \\
\text { of Suicide Ideation and the } \\
\text { BSSI (Beck et al., 1988) }\end{array}$ & $\begin{array}{l}\text { Three factors: Desire for } \\
\text { Death, Preparation for death } \\
\text { and Active Suicidal Desire } \\
\text { (Steer et al., 1993) }\end{array}$ & $\begin{array}{l}\text { Detected clinically } \\
\text { significant changes in } \\
\text { suicidal ideation in } \\
\text { participants receiving online } \\
\text { self-help treatment for } \\
\text { suicidal thoughts (van } \\
\text { Spijker, van Straten, \& } \\
\text { Kerkhof, 2012). Associated } \\
\text { with decreases in suicidality } \\
\text { in } 73 \text { people depressed youth } \\
\text { (14 -24 years) who } \\
\text { completed an Interpersonal } \\
\text { Psychotherapy intervention. } \\
\text { Requires further } \\
\text { investigation. }\end{array}$ \\
\hline
\end{tabular}




\begin{tabular}{|c|c|c|c|c|c|c|}
\hline \multirow[t]{2}{*}{ Measure } & \multirow[t]{2}{*}{ Sample } & \multicolumn{2}{|c|}{ Reliability $^{\text {ab }}$} & \multicolumn{2}{|l|}{ Validity $^{\mathbf{b}}$} & \multirow[b]{2}{*}{ Sensitivity to change } \\
\hline & & $\begin{array}{l}\text { Internal } \\
\text { consistency }\end{array}$ & Test-retest & Concurrent & Construct & \\
\hline CHRT-SR & $\begin{array}{l}\text { Testing population: } \\
240 \text { non-psychotic } \\
\text { outpatients taking selective } \\
\text { serotonin reuptake inhibitors } \\
\text { Used with: } \\
\text { Adult outpatients }\end{array}$ & $\begin{array}{l}\text { Acceptable } \\
(\alpha=.78) \\
\text { (Trivedi et al., } \\
2011)\end{array}$ & Not reported. & $\begin{array}{l}\text { Correlated with the Positive } \\
\text { Suicide and Negative Suicide } \\
\text { Ideation Inventory ( } r=.69 \text { ). } \\
\text { High agreement between the } \\
\text { self-rated and clinician rated } \\
\text { versions ( } \kappa \text { ranging from.63 } \\
\text { to.81) (Trivedi et al., 2011). }\end{array}$ & $\begin{array}{l}\text { Three factors: hopelessness, } \\
\text { perceived lack of support and } \\
\text { active suicidal thoughts and } \\
\text { plans. Each correlated with the } \\
\text { total score, all loading }>.70 \\
\text { (Trivedi et al., 2011). }\end{array}$ & Not reported. \\
\hline \multirow[t]{2}{*}{ HASS } & $\begin{array}{l}\text { Populations tested: } \\
661 \text { High school students } \\
131 \text { Pediatric emergency } \\
\text { department patients } \\
\text { Used with: } \\
\text { Adult psychiatric inpatients } \\
\text { and outpatients } \\
\text { Adults with HIV }\end{array}$ & $\begin{array}{l}\text { Acceptable to } \\
\text { excellent } \\
\text { ( } \alpha \text { range } .77- \\
.96) \text { in youth } \\
\text { (Asarnow, } \\
\text { Baraff, Berk et } \\
\text { al., 2011) }\end{array}$ & $\begin{array}{l}\text { Good over } 116 \\
\text { days }(\mathrm{r}=.54) \text { in } \\
\text { pediatric } \\
\text { emergency } \\
\text { population } \\
\text { (Asarnow et al., } \\
\text { 2011) }\end{array}$ & $\begin{array}{l}\text { HASS suicidal attempt items } \\
\text { correlated with the Diagnostic } \\
\text { Interview SC -IV suicidal } \\
\text { attempt items.(Asarnow, } \\
\text { McArthur, Hughes et al., } \\
2012) \\
\text { Moderately correlated with } \\
\text { Beck Depression Inventory ( } r \\
=.58), \text { Hamilton Depression } \\
(r=.50), \text { Beck Hopelessness } \\
\text { Scale }(r=.56) \text {.(Harkavy- } \\
\text { Friedman, Nelson, Venarde et } \\
\text { al., 2004) }\end{array}$ & $\begin{array}{l}\text { HASS I: three factors - } \\
\text { passive suicidal behavior, } \\
\text { active suicidal behavior and } \\
\text { substance abuse. HASS II: } \\
\text { four factors - thoughts of } \\
\text { suicide, substance use, } \\
\text { thoughts of death, and } \\
\text { suicidal plans and actions. } \\
\text { Correlation with DISC IV } \\
\text { ratings of sensitivity was } \\
\text { excellent (100\%) (Asarnow et } \\
\text { al., 2012) }\end{array}$ & $\begin{array}{l}\text { Sensitive to treatment } \\
\text { changes for youth in } \\
\text { emergency departments } \\
\text { (Asarnow et al., 2012) }\end{array}$ \\
\hline & & $\begin{array}{l}\text { Not reported in } \\
\text { adults. }\end{array}$ & $\begin{array}{l}\text { Not reported in } \\
\text { adults. }\end{array}$ & & Not reported in adults. & Not reported in adults. \\
\hline S-STS & $\begin{array}{l}\text { Populations tested: } \\
82 \text { Female adult outpatients } \\
\text { with generalized anxiety } \\
\text { disorder } \\
330 \text { Undergraduate Italian } \\
\text { students } \\
\text { Used with: } \\
\text { Outpatients } \\
\text { Antidepressant trials } \\
\text { Undergraduate student } \\
\text { Depressed adults }\end{array}$ & $\begin{array}{l}\text { Very good } \\
\text { (Guttman's } \lambda \\
\text { range .83-.88) } \\
\text { (Preti, Sheehan, } \\
\text { Coric et al., } \\
\text { 2013) }\end{array}$ & $\begin{array}{l}\text { Good for S-STS } \\
\text { Global Scale }(r= \\
.67) \text { and S-STS } \\
\text { Suicidal Ideation } \\
\text { Subscale ( } r= \\
\text {.76); poor for S- } \\
\text { STS Suicidal } \\
\text { Behavior } \\
\text { Subscale }(r=.36) \\
\text { over 4-6 weeks } \\
\text { (Preti et al., 2013) }\end{array}$ & $\begin{array}{l}\text { Correlated with GHQ }(r=.21) \\
\text { and with Rosenberg Self- } \\
\text { Esteem Scale }(r=-.30) \text { and } \\
\text { Modified Social Support } \\
\text { Survey ( } r=-.21) \text { (Preti et al., } \\
\text { 2013) }\end{array}$ & $\begin{array}{l}\text { One factor with all factor } \\
\text { loadings } \geq .70 \text { (Preti et al., } \\
2013 \text { ) }\end{array}$ & $\begin{array}{l}\text { In a double blind } \\
\text { randomized control trial of } \\
80 \text { patients prescribed } \\
\text { citalopram and /or lithium, } \\
\text { the S-STS showed } \\
\text { improvement over four week } \\
\text { period.(Khan, Khan, Hobus } \\
\text { et al., 2011) }\end{array}$ \\
\hline
\end{tabular}




\begin{tabular}{|c|c|c|c|c|c|c|}
\hline \multirow[t]{2}{*}{ Measure } & \multirow[t]{2}{*}{ Sample } & \multicolumn{2}{|c|}{ Reliability $^{\text {ab }}$} & \multicolumn{2}{|l|}{ Validity $^{\mathbf{b}}$} & \multirow[b]{2}{*}{ Sensitivity to change } \\
\hline & & $\begin{array}{l}\text { Internal } \\
\text { consistency }\end{array}$ & Test-retest & Concurrent & Construct & \\
\hline YES & $\begin{array}{l}\text { Populations tested: } \\
309 \text { Bereaved adults } \\
\text { Used with: } \\
\text { Advanced cancer patients } \\
\text { Geriatric patients } \\
\text { People with substance abuse }\end{array}$ & $\begin{array}{l}\text { Good }(\alpha=.80) \\
\text { (Latham \& } \\
\text { Prigerson, 2004) }\end{array}$ & $\begin{array}{l}\text { Good over } 18 \\
\text { weeks }(r=.70) \\
\text { (Latham \& } \\
\text { Prigerson, 2004) }\end{array}$ & $\begin{array}{l}\text { Higher YES scores associated } \\
\text { with symptoms of depression, } \\
\text { generalized anxiety and post- } \\
\text { traumatic stress (Latham \& } \\
\text { Prigerson, 2004) }\end{array}$ & $\begin{array}{l}\text { T scores } \geq 23.02 \text { associated } \\
\text { with } 2.69 \text { times }(\mathrm{p}<0.0001) \\
\text { greater likelihood of } \\
\text { indicating plans of a suicide } \\
\text { attempt (Latham \& Prigerson, } \\
\text { 2004) }\end{array}$ & Not reported. \\
\hline \multicolumn{7}{|c|}{ Brief measures } \\
\hline DSI-SS & $\begin{array}{l}\text { Population tested: } \\
2851 \text { (15-24 years) in } \\
\text { Australian primary care } \\
\text { Used with: } \\
\text { Youth } \\
\text { Homeless youth } \\
\text { Adults } \\
\text { Geriatric population in } \\
\text { primary care } \\
\text { Community samples }\end{array}$ & $\begin{array}{l}\text { Excellent }(\alpha= \\
.90)(\text { Joiner et } \\
\text { al., 2002) }\end{array}$ & Not reported. & $\begin{array}{l}\text { Correlated with Center for } \\
\text { Epidemiological Studies } \\
\text { Depression Scale }(r=.60) \text { and } \\
\text { General Health Questionnaire } \\
(r=.49) \text { (Joiner et al., 2002) }\end{array}$ & $\begin{array}{l}\text { One factor on which all } 4 \\
\text { items strongly loaded (all } \\
\text { loading }>.75 \text { ) (Joiner et al., } \\
2002 \text { ) }\end{array}$ & Not reported. \\
\hline $\begin{array}{l}\text { PSF } \\
\text { (Suicide } \\
\text { Items) }\end{array}$ & $\begin{array}{l}\text { Populations tested: } \\
3053 \text { British } 43 \text { year olds } \\
\text { Used with: } \\
\text { Whole scale used in } \\
\text { National Survey in UK } \\
\text { People with intellectual } \\
\text { disability } \\
\text { Suicide items used with: } \\
\text { Australian adult population }\end{array}$ & $\begin{array}{l}\text { Not reported for } \\
\text { suicide items. }\end{array}$ & $\begin{array}{l}\text { Not reported for } \\
\text { suicide items. }\end{array}$ & Not reported for suicide items. & Not reported for suicide items. & \\
\hline
\end{tabular}




\begin{tabular}{|c|c|c|c|c|c|c|}
\hline \multirow[t]{2}{*}{ Measure } & \multirow[t]{2}{*}{ Sample } & \multicolumn{2}{|c|}{ Reliability $^{\text {ab }}$} & \multicolumn{2}{|l|}{ Validity $^{\mathbf{b}}$} & \multirow[b]{2}{*}{ Sensitivity to change } \\
\hline & & $\begin{array}{l}\text { Internal } \\
\text { consistency }\end{array}$ & Test-retest & Concurrent & Construct & \\
\hline SBQ-R & $\begin{array}{l}\text { Populations tested: } \\
120 \text { Adult inpatients } \\
120 \text { Adolescent inpatients } \\
138 \text { High school students } \\
135 \text { Undergraduates } \\
\text { Used with: } \\
\text { Adolescents } \\
\text { Outpatients } \\
\text { Inpatients } \\
\text { Undergraduates } \\
\text { Incarcerated adolescents } \\
\text { Community samples }\end{array}$ & $\begin{array}{l}\text { Good in } \\
\text { adolescents and } \\
\text { high school } \\
\text { students }(\alpha \\
\text { range } .87-.88) \\
\text { Acceptable to } \\
\text { good in adult } \\
\text { population ( } \alpha \\
\text { range } .76-.87) \\
\text { (Osman et al., } \\
\text { 2001) }\end{array}$ & $\begin{array}{l}\text { Excellent test- } \\
\text { retest }(r=.95) \\
\text { over } 2 \text { weeks } \\
\text { (Cotton, Peters, \& } \\
\text { Range, 1995) }\end{array}$ & $\begin{array}{l}\text { Correlated with Scale for } \\
\text { Suicidal Ideation }(r=.69) \text { and } \\
\text { negatively correlated with } \\
\text { Reasons For Living Sale ( } r=- \\
.34 \text { ) (Cotton et al., 1995) }\end{array}$ & $\begin{array}{l}\text { No factors identified } \\
\text { A cut off of } 8 \text { demonstrated } \\
\text { excellent sensitivity in } \\
\text { discriminating between } \\
\text { suicidal and non-suicidal } \\
\text { patients (Osman et al., 2001) }\end{array}$ & Not reported. \\
\hline SIDAS & $\begin{array}{l}\text { Populations tested: } \\
1352 \text { Online Australian } \\
\text { community population }\end{array}$ & $\begin{array}{l}\text { Excellent }(\alpha= \\
.91)(\text { van } \\
\text { Spijker et al., } \\
\text { 2014) }\end{array}$ & Not reported. & $\begin{array}{l}\text { Correlated with Columbia } \\
\text { Severity Index ( } r \text { range .44- } \\
.61) \text {, Patient Health } \\
\text { Questionnaire-9 ( } r=.65) \text {, } \\
\text { Generalized Anxiety Disorder- } \\
7(r=.58) \text { and Insomnia } \\
\text { Severity Index }(r=.40) \text { (van } \\
\text { Spijker et al., 2014) }\end{array}$ & $\begin{array}{l}\text { One factor on which all items } \\
\text { moderately loaded (all loading } \\
>0.6 \text { ). ROC analyses } \\
\text { indicated scores } \geq 21 \text { indicate } \\
\text { a higher risk of suicide } \\
\text { attempt (van Spijker et al., } \\
\text { 2014) }\end{array}$ & Not reported. \\
\hline
\end{tabular}

${ }^{a}$ Cronbach's $\alpha$ values indicate: $\geq .90$ excellent; $.80-.89=$ good; $.70-.79=$ acceptable; $.60-.69$ questionable; $.50-.59$ poor and $<.50$ unacceptable

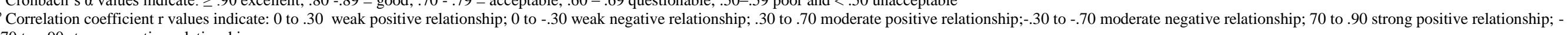
.70 to -.90 strong negative relationship 


\section{University Library}

\section{- M M I N E R VA \\ A gateway to Melbourne's research publications}

Minerva Access is the Institutional Repository of The University of Melbourne

Author/s:

Batterham, PJ;Ftanou, M;Pirkis, J;Brewer, JL;Mackinnon, AJ;Beautrais, A;Fairweather-

Schmidt, AK;Christensen, $\mathrm{H}$

Title:

A Systematic Review and Evaluation of Measures for Suicidal Ideation and Behaviors in Population-Based Research

Date:

2015-06-01

Citation:

Batterham, P. J., Ftanou, M., Pirkis, J., Brewer, J. L., Mackinnon, A. J., Beautrais, A., Fairweather-Schmidt, A. K. \& Christensen, H. (2015). A Systematic Review and Evaluation of Measures for Suicidal Ideation and Behaviors in Population-Based Research. PSYCHOLOGICAL ASSESSMENT, 27 (2), pp.501-512. https://doi.org/10.1037/pas0000053.

Persistent Link:

http://hdl.handle.net/11343/58465 